\title{
Effect of phosphorus and PSB on growth, nodulation and fertility status in different mungbean (Vigna radiata L.) varieties and its residual effect on fodder yield of sorghum in indo-gangetic plain zone of India
}

\author{
S.N. Dubey*, Rajpal Singh, Rohit Kumar and Sauhard Dubey \\ Department of Agronomy, A.S. (P.G.) College, Lakhaoti, BULANDSHAHR (U.P.) INDIA \\ (Email:9411052527S@gmail.com)
}

\begin{abstract}
A field experiment was conducted during sammer and Kharif season of 2010 and 2011 at research farm of A. S, (PG) College, Lakhaoti, Bulandsahar, U.P. to Studies on phosphorus and PSB management in different varieties of summer mungbean and its effect on succeeding fodder sorghum. The Experiment was laid out in a Factorial Randomized Block Design (FRBD) keeping three-treatments of bold seeded green gram varieties (Pant-moong-5, Pusa Vishal, Pusa 9531) of in main plots and six treatments of phosphorus and biofertilizers in sub-plots. Results revealed that the different varieties of mungbean to phosphorus upto $50 \mathrm{~kg} \mathrm{P}_{2} \mathrm{O}_{5}$ ha $^{-1}$ and inoculation of seed with PSB $\left(25 \mathrm{~kg} \mathrm{ha}^{-1}\right)$ increased the plant height $(49.13$ and $51.15 \mathrm{~cm})$, number of nodules plant ${ }^{-1}\left(17.35\right.$ and 16.50) and availability of nutrient $\mathrm{N}$ (361 and $\left.364 \mathrm{~kg} \mathrm{ha}^{-1}\right), \mathrm{P}\left(13.23\right.$ and $13.36 \mathrm{~kg} \mathrm{ha}^{-1}$ ) except K and green fodder yield (546 q ha-1 at harvest time ) of succeeding fodder sorghum crop .
\end{abstract}

Key Words : Availability, Biofertilizers, Mungbean, Phosphorus, Sorghum, Yield

View Point Article : Dubey, S.N., Singh, Rajpal, Kumar, Rohit and Dubey, Sauhard (2018). Effect of phosphorus and PSB on growth, nodulation and fertility status in different mungbean (Vigna radiata L.) varieties and its residual effect on fodder yield of sorghum in indogangetic plain zone of India. Internat. J. agric. Sci., 14 (1) : 196-201, DOI:10.15740/HAS/IJAS/14.1/196-201.

Article History : Received : 12.07.2017; Revised : 01.12.2017; Accepted : 13.12.2017

* Author for correspondence: 